\title{
Multimedia physics practicum reflective material based on problem solving for science process skills
}

\author{
Wawan Kurniawan, Darmaji Darmaji, Astalini Astalini, Dwi Agus Kurniawan, M. Hidayat, \\ Nugroho Kurniawan, Linda Zaenati Nur Farida \\ Faculty of Teaching and Education, Universitas Jambi, Indonesia
}

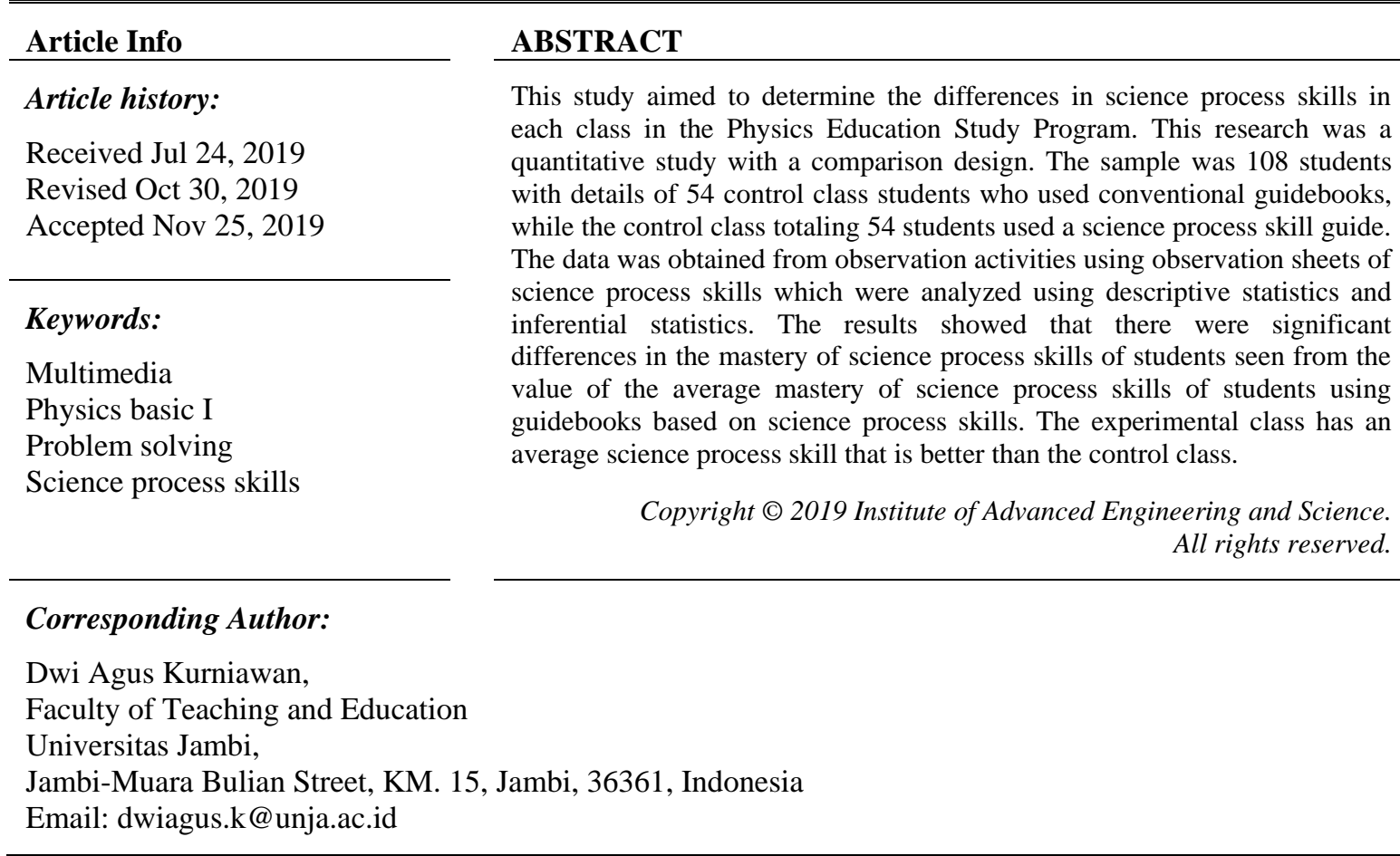

\section{INTRODUCTION}

One of the many materials about the style learned in basic physics courses is friction. Friction occurs due to two surfaces that are in contact with each other and in opposite directions. Friction force is divided into two types, namely the frictional force between two surfaces mutually silent one another called frictional forces static $\left(F_{s}\right)$, the coefficient of friction is called the coefficient of static friction $\left(\mu_{\mathrm{s}}\right)$ and the friction between the two surfaces move relative to each other which is called the kinetic frictional force $\left(F_{k}\right)$, called the friction coefficient of kinetic friction coefficient $\left(\mu_{\mathrm{k})}[1]\right.$.

To develop a range of knowledge about friction, it is not enough for students to just learn concepts or theories but need to be accompanied by a process of scientific inquiry. This is based on learning physics as part of science. Science consists of two aspects, namely science known as scientific inquiry (process) and science known as body of knowledge (product) [2]. One of the processes of scientific inquiry can be carried out by practical activities. Tat one way for someone to obtain and develop a set of knowledge they have is through practical activities [3]. Learning activity would feel more meaningful if accompanied by practical activities [4].

Practicum is an activity of conducting experimental or experimental practices [5]. Practical activity was more effective in fostering students' acquisition of science process skills [6]. That the process of discovery carried out through practical activities can improve student science process skills [7]. Science process skills are considered to give students meaningful learning experiences because they help students to achieve high-level thinking and critical thinking [8]. Where critical thinking is the initial foundation for the development of creative thinking [9]. Mastering science process skills allows students to acquire the skills needed to solve everyday problems [10]. Science process skills are thinking skills used to process 
information, solve problems, and form conclusions [11]. Science process skills are the drivers of the discovery and development of facts and concepts and growth and the development of attitudes and values [12]. The importance of mastering science process skills by students can facilitate students in understanding abstract concepts if they learn through concrete objects and are done alone by students through direct learning experiences. Learning through experience can be done directly through practical activities [13].

Practicum activities would run well and smoothly when supplemented with a multimediabook [14]. The multimediabook is a book that is compiled to assist in the implementation of practicum which contains the experimental title, objectives, theoretical basis, tools and materials, and questions that lead to goals by following the rules of scientific writing. Practicum guidance as one of the learning resources in practical activities should be a guide for students in developing science process skills. Therefore, it is important in the basic physics practicum guide to contain aspects of science process skills [15].

Research on science process skills of students in basic physics practicum 1 friction material had previously been carried out where in the findings of the study were science process skills in the overall friction practice students had skills that were classified as very unskilled. Therefore, it is necessary to carry out multimedialine implementation research based on science process skills by using a problem solving model to see differences in mastery of science process skills between students who use science process-based practical guidance and students who use conventional multimediabooks. Where later the results of this study can be used as a basis for consideration for physics education study programs in applying guidance-based science process skills

\section{RESEARCH METHOD}

This study employed quantitative approach with a statistical group comparative research design. This research was conducted in the laboratory of the Jambi University Teacher Training and Education Faculty Physics Study Program in the odd semester of 2018 academic year. The samples taken in this study were all physics education students taking 108 basic physics courses divided into experimental and class classes. control. The sampling technique used in this study used total sampling technique. Total sampling technique is a sampling technique if all members of the population are used as samples [16]. Samples from 54 people in the experimental class and 54 in the control group will be formed into groups with each group consisting of 4 to 5 students. Then students in the experimental class were given treatment to provide science process skills-based practicum with friction material while students in the control class used conventional laboratory guidelines. Furthermore, students in each practicum group used tools and materials provided by the researcher.

The instrument used in this study is the observation sheet of science process skills. Observations made in this study were assisted by observers totaling 20 people. Data on the observation sheet will be analyzed using Use descriptive statistics to see the mastery of indicators of science process skills in the experimental class and the control class. The normal prerequisite test in this study used the KolmogorovSmirnov test with normality testing criteria based on probability values. If the probability (sig.) $>0.05$, the data is normally distributed. If the probability $(\mathrm{sig})<0.05$, then the data is not normally distributed [17]. The homogeneity prerequisite test in this study uses the Levene test with testing criteria, if the significance value is more than 0.05 , it can be said that the variance of the two groups of data is the same so that the test students using the same variance are assumed and if the significance value is smaller than 0.05 , it can be said that the variance of the two groups of data is not the same so that student tests using the same variance are not assumed [17]. The research hypothesis test uses an independent sample t-test. The output of the independent sample test can be seen based on the value of $t$, that is if count <ttable, then $\mathrm{H}_{0}$ is accepted and if $\mathrm{t}$-count $>\mathrm{t}$-table, then $\mathrm{H}_{0}$ is rejected or based on the value of sig. (2-tailed)>, then $\mathrm{H}_{0}$ is accepted and if sig. (2-tailed) < then $\mathrm{H}_{0}$ is rejected [17].

\section{RESULTS AND DISCUSSION}

\subsection{Data descriptive analysis results}

The results of the descriptive analysis of mastery of science process skills in the experimental class and the control class of physics education students in the 2018/2019 academic year are shown in Table 1 . Based on Table 1, it can be seen that the results of mastery of the experimental class science process skill indicators are higher than the mastery of the experimental science process skills.

Mastery of the process skills most mastered in the experimental class is an indicator of observation skills. The indicator of observation skills in the experimental class has a mean value of 3.54, median value of 3.50 , and the mode value is 3.25. Similar to the experimental class, the observation skills indicator is also an indicator of science process skills that is mostly controlled by the control class, but the average mastery is 
still low compared to the experimental class. The indicator of observation skills in the control class has a mean value of 2.98 , median value of 3.00 , and the mode value is 2.75 .

Table 1. Skills for making data tables for experimental

\begin{tabular}{clccccc}
\multicolumn{7}{c}{ classes and control classes } \\
\hline Indicator & Class & Mean & Median & Mode & Min & Max \\
\hline Observation & Experiment & 3.54 & 3.50 & 3.25 & 2.75 & 4.00 \\
& Control & 2.98 & 3.00 & 2.75 & 2.50 & 3.75 \\
Prediction & Experiment & 3.06 & 3.00 & 3.00 & 2.00 & 4.00 \\
& Control & 2.51 & 2.00 & 2.00 & 1.00 & 4.00 \\
Classification & Experiment & 3.31 & 3.00 & 3.00 & 2.00 & 4.00 \\
& Control & 2.96 & 3.00 & 3.00 & 1.00 & 4.00 \\
\hline
\end{tabular}

\subsection{Analysis of prerequisites for normality}

The analysis of test prerequisites for the mastery of process skills using normality tests is presented in Table 2. The table shows that the significance values in the Kolmogorov-Smirnov test for the experimental class is 0.062 and for the control class is 0.200 .

Table 2. Results of the analysis of the normality test of mastery of science process skills (SPS) in experimental classes and control classes

\begin{tabular}{lccc}
\hline \multicolumn{1}{c}{ CLASS } & \multicolumn{3}{c}{ Kolmogorov-Smirnov ${ }^{\text {a }}$} \\
& Statistics & df & Sig. \\
\hline Experimental Class & .117 & 54 & .062 \\
Control Class & .078 & 54 & $.200^{*}$ \\
\hline
\end{tabular}

The criteria for testing normality based on probability values are if the value of significance (sig.) is greater than 0.05 then the data is normally distributed. Therefore the significance value for the executive class and the control class is greater than 0.05 ; then the data mastery of science process skills in both the experimental class and the control class has a normal distribution at the 5\% significance level.

\subsection{Analysis of homogeneity prerequisite test results and hypothesis testing}

Levene's test or variance assumption test is a prerequisite test before analyzing independent sample t-test. In Levene's test, if there is no difference in variance in the data, then the t-test uses the Equal variances assumed and if there are differences in the variance in the data, then the t-test uses Equal variances not assumed. In Table 3, (Levene's Test for Equality of Variances column), it can be seen that the significance value (sig.) of process skill mastery data is 0.256 . Because the significance value of the data mastery of science process skills is greater than 0.05; then there is no difference in data variance between the experimental class and the control class. The Lavene's testing criteria based on probability values are if the value of significance (sig.) is greater than 0.05 then it is not there are different variants in the data. Therefore, the test of the independent sample t-test uses the Equal variances assumed.

Furthermore, an analysis of the results of the independent sample t-test is presented in Table 2. From the table, it can be seen that the probability value of sig. (2-tailed) data mastery of science process skills is 0.000 . Therefore, the value of sig. (2-tailed) process skill mastery data smaller than 0.05 ; then $\mathrm{H}_{0}$ is rejected, meaning that there are a different science process skills that students significantly between the experimental class and control class in Physics Education Study Program after guiding applied science process skills-based lab using a model of problem solving with a 5\% significance level. The criteria for testing the hypothesis in the test of the independent sample $\mathrm{t}$-test are if the probability value is sig. (2-tailed) less than 0.05 ; then $\mathrm{H}_{0}$ is rejected.

Besides being seen from the probability value of significance, hypothesis testing can also be seen from comparing the values of $t$ obtained $\left(t_{\text {count }}\right)$ with $t$ table values. The value of $t_{\text {table }}$ can be found in the statistical table at the significance of 0.025 (2-sided test) with the degree of freedom (df) 106. In this study, the results for $t_{\text {table }}$ are 1.982. The calculated $t$ value can be seen in Table 3. (Column $t$ ) which is 20,993. The hypothesis testing criteria are the value of $t_{\text {count }}$ is greater than the value of $t_{\text {table }}$ then there is a rejection of $\mathrm{H}_{0}$. So, it can be concluded that there are differences in the mastery of science process skills that are significant between the experimental class and the control class after the guidance based on science process skills is applied using a problem solving the model 
Table 3. Statistics group results of comparative analysis of mastery of science process skills (SPS) class experiments and control classes using independent sample t-test

\begin{tabular}{|c|c|c|c|c|c|}
\hline & Class & $\mathrm{N}$ & Mean & Std. Deviation & Std. Mean Error \\
\hline \multirow[t]{2}{*}{ KPS } & Experiment & 54 & 3.1385 & .23762 & .03234 \\
\hline & Control & 54 & 2.1091 & .27091 & .03687 \\
\hline
\end{tabular}

Table 3 displays about data group statistics. Based on the table it can be seen that the amount of data $(\mathrm{N})$ in the experimental class is 54 and has a mean of 3.1385 with a standard deviation of 0.23762 . For the control, the class has a number of data 54 with a mean of 2.1091 and a standard deviation of 0.27091 . Based on the aforementioned parameters, it can be concluded that the average mastery of science process skills in the experimental class using science process skills based guidance using a problem solving model is better than the average mastery of science process skills in the control class using conventional guides

Based on the findings in this study, it can be seen that the use of practical guidance based on science process skills by using the problem solving model helps experimental class students to practice science process skills. The presentation of problems regarding practicum contained in the initial section of the guide directs experimental students to various activities such as observing, predicting, interpreting, applying concepts, planning experiments and communicating the results. Based on the observation sheet data, the experimental class students have been good at mastering the indicators of science process skills. However, the indicator of the process skills most mastered in the experimental class is an indicator of observation skills. This is supported by documentation data in the form of images.

The high level of mastery of the indicators of the observation process skills based on all forms of learning activities both in the classroom and in the laboratory begins with an observation. Observation skills are the most basic skills of students when conducting experiments [18]. Almost every activity of science begins with observation. In addition, observation skills are the most basic skills that support the mastery of the next skill [19]. Observing is a fundamental skill which is the main basis of the growth of science, which helps independent students in solving a case, think creatively and think critically [20].

The presentation of the initial questions about the material practiced requires students to have initial knowledge so that when doing a practicum, students already understand what must be done both in determining the tools and materials to be used as well as how to design experiments to get the desired data. Students must have the initial knowledge before conducting practical activities because this will help assist them in following the lab learning process. In addition, initial knowledge can be the basis for students to develop further knowledge [21]. Initial knowledge possessed by students/students is the basis for building their next knowledge. This initial question is summarized in the form of an interim report.

The low science process skills in the control class are influenced by the use of conventional guidebooks, where the work steps contained in conventional guides are presented in detail. This can cause reasoning ability to solve the problems presented by students to be low and students cannot think critically in determining what actions to take in designing the experiment. Students who are less active in an activity, they will have progress individually according to their knowledge and abilities, which affect student motivation [22-26].Use of practicum instructions that are too detailed results in less stimulating students to develop their reasoning power to plan and solve problems they face, this, of course, will have an effect on mastering process skills they $[5,27,28]$.

This research is a follow-up research from the previous research with the title "Development of a book for the preservation of basic physics practicum I based on science process skills using a problem solving model on friction material" in 2018. However, the research only reached the stage of developing the product test on small classes. Therefore, this research was conducted on all physics education students who contracted basic physics courses I. The study also provided additional information about students' science process skills so that they could be taken into consideration for physics education programs and other study programs to apply teaching materials and multimedia based on science process skills.

There are several factors that become obstacles for students when doing a practicum. These obstacles are seen when the practical process is in progress. The obstacle factors are: 1) the lack of use of the picture in the guidebook makes it difficult for students to design the trial scheme; 2) The use of language that is less communicative in the work procedures section makes it difficult for students to determine the steps of work to be done.

Based on the findings in this study, it can be seen that the use of practical guidance based on science process skills by using the problem solving model helps experimental class students to practice science process skills. The presentation of problems regarding practicum contained in the initial section of the guide directs experimental students to various activities such as observing, predicting, interpreting, applying concepts, planning experiments and communicating the results. Based on the observation sheet data, the experimental class students have been good at mastering the indicators of science process skills. However, 
the indicator of the process skills most mastered in the experimental class is an indicator of observation skills. This is supported by documentation data in the form of images.

The high level of mastery of the indicators of the observation process skills based on all forms of learning activities both in the classroom and in the laboratory begins with an observation. Observation skills are the most basic skills of students when conducting experiments [18, 29, 30]. Almost every activity of science begins with observation. In addition, observation skills are the most basic skills that support the mastery of the next skill [19]. Observing is a fundamental skill which is the main basis of the growth of science, which helps independent students in solving a case, think creatively and think critically [20].

The presentation of the initial questions about the material practiced requires students to have initial knowledge so that when doing a practicum, students already understand what must be done both in determining the tools and materials to be used as well as how to design experiments to get the desired data. Students must have the initial knowledge before conducting practical activities because this will help assist them in following the lab learning process. In addition, initial knowledge can be the basis for students to develop further knowledge [21]. Initial knowledge possessed by students/students is the basis for building their next knowledge. This initial question is summarized in the form of an interim report.

The low science process skills in the control class are influenced by the use of conventional guidebooks, where the work steps contained in conventional guides are presented in detail. This can cause reasoning ability to solve the problems presented by students to be low and students cannot think critically in determining what actions to take in designing the experiment. Students who are less active in an activity, they will have progress individually according to their knowledge and abilities, which affect student motivation [22-24].Use of practicum instructions that are too detailed results in less stimulating students to develop their reasoning power to plan and solve problems they face, this, of course, will have an effect on mastering process skills they [5].

This research is a follow-up research from the previous research with the title "Development of a book for the preservation of basic physics practicum I based on science process skills using a problem solving model on friction material" in 2018. However, the research only reached the stage of developing the product test on small classes. Therefore, this research was conducted on all physics education students who contracted basic physics courses I. The study also provided additional information about students' science process skills so that they could be taken into consideration for physics education programs and other study programs to apply teaching materials and multimedia based on science process skills.

There are several factors that become obstacles for students when doing a practicum. These obstacles are seen when the practical process is in progress. The obstacle factors are: 1) the lack of use of the picture in the guidebook makes it difficult for students to design the trial scheme; 2) The use of language that is less communicative in the work procedures section makes it difficult for students to determine the steps of work to be done.

\section{CONCLUSION}

There is a significant difference in the mastery of process skills between the experimental class and the control class. Based on the statistical parameters used, it can be concluded that the average mastery of science process skills in the experimental class using science process skills based guidance using a problem solving model is better than the average mastery of science process skills in the control class using conventional guides.

The addition of experimental illustration images on the multimedia is expected to help students in designing the trial scheme. The use of more communicative language can help students in determining actions in work procedures.

\section{REFERENCES}

[1] Halliday, D., Walker, J., \& Resnick, R. Fundamentals of physics. John Wiley \& Sons. 2013.

[2] Akinbobola, A. O., \& Afolabi, F. "Analysis of science process skills in West African senior secondary school certificate physics practical examinations in Nigeria," American-Eurasian Journal of Scientific Research, vol. 5(4), pp. 234-240, 2010.

[3] Thiel, R. P., \& George, K. D. "Some factors affecting the use of the science process skill of prediction by elementary school children," Journal of research in Science Teaching, vol. 13(2), pp. 155-166. 1976.

[4] Hafizan, E., Halim, L., \& Meerah, T. S. "Perception, conceptual knowledge and competency level of integrated science process skill towards planning a professional enhancement programme," Sains Malaysiana, vol. 41(7), 921930, 2012. 
[5] Etiubon, R. U., \& Udoh, N. M. (2017). "Effects of practical activities and manual on science students' academic performance on solubility in Uruan Local Education Authority of Akwa Ibom State," Journal of Education and Practice, vol. 8(3), pp. 202-209, 2017.

[6] Nwagbo, C., \& Chukelu, U. C. "Effects of biology practical activities on students' process skill acquisition," Journal of the Science Association of Nigeria (JSTAN), vol. 46(1), pp. 58-70, 2017.

[7] Yavad \& Mishra., "A study of the impact of laboratory approach on achievement and process skill in science among is standart students," International Journal Of Scientific and Research Publication, vol. 3(1), pp. 2, 2013.

[8] Tilakaratnea, C. TK \& Ekanayakeb, TMSSKY, "Achievement of the science process skills for junior secondary students: Based on a sample of grade six and seven students from Sri Lanka," International Journal of Environmental \& Science Education, vol. 12(9), pp. 2089-2108, 2017.

[9] Khoroshikh, P. P., Sergievich, A. A., \& Platonova, R. I. "Development of students' critical thinking by active and interactive training methods," TEM Journal-Technology Education Management Informatics, vol. 7(4), pp. 787790, 2018

[10] Kazeni, M. M. M., Development and validation of a test integrated science process skills for the further education and training learners. (Unpublished Master Thesis), University of Pretoria South Africa. 2005

[11] Ozgelen, S., "Students science process skills within the cognitive domain framework," Eurasian Journal of Mathematics, Science \& Technology Education, vol. 8(4), pp. 283-292, 2012.

[12] Zeidan, A. H., \& Jayosi, M. R., "Science process skills and attitudes toward science among palestinian secondary school students," World journal of Education, vol. 5(1), pp. 13-24, 2015.

[13] Opateye, J. A. "Developing and assessing science and technology process skills (STPSs) in Nigerian Universal basic education environment," Journal of Educational and Social Research, 2011.

[14] Wiwin, E., \& Kustijono, R. "The use of physics practicum to train science process skills and its effect on scientific attitude of vocational high school students," In Journal of Physics: Conference Series, vol. 997(1), pp. 012040. IOP Publishing, 2018.

[15] Gobaw, G. F., \& Atagana, H. I. "Assessing laboratory skills performance in Undergraduate Biology Students," Academic Journal of Interdisciplinary Studies, vol. 5(3), pp. 113, 2016

[16] Cohen, L., Manion, L., \& Morrison, K. Research methods in education. routledge. 2002.

[17] Cramer, D. Advanced quantitative data analysis. McGraw-Hill Education (UK). 2003.

[18] Monhardt, L., \& Monhardt, R. "Creating a context for the learning of science process skills through picture books," Early Childhood Education Journal, vol. 34(1), pp. 67-71, 2006.

[19] Ango, M. L. "Mastery of science process skills and their effective use in the Teaching of Science," An Educology of Science Education in the Nigerian Context, vol. 16(1), pp, 11-30, 2002.

[20] Downing, J. E., \& Gifford, V. "An investigation of preservice teachers' science process skills and questioning strategies used during a demonstration science discovery lesson," Journal of Elementary Science Education, vol. 8(1), pp. 64, 1996.

[21] Beaumont-Walters, Y., \& Soyibo, K. "An analysis of high school students' performance on five integrated science process skills," Research in Science \& Technological Education, vol. 19(2), pp. 133-145. 2001

[22] Kudumovic, M., \& Aleksic, D. "Application of electronic learning in the educational education work of the classroom teaching and teaching," TEM Journal-Technology Education Management Informatics, vol. 7(4), pp. 869-874, 2018.

[23] Asrial, A., Syahrial, S., Kurniawan, D. A., Subandiyo, M., Amalina, N. "Exploring obstacles in language learning among prospective primary school teacher," International Journal of Evaluation and Research in Education, vol. 8(2), pp. 249-254, 2019.

[24] Asrial, A., Syahrial, S., Kurniawan, D. A., Suabndiyo, M., Amalina, N. "Description of Elementary Teacher Education Program's Student: Mapping Indonesian Language competence for prospective teacher," The Educational Review, USA, vol. 3(2), pp. 21-27. 2019.

[25] Dogan, I., \& Kunt, H. "Determination of prospective preschool teachers' science process skills," Journal Of European Education, vol. 6(1), pp. 8-18, 2017. https://doi.org/10.18656/jee.65104

[26] Behera, S., Dr. C.V. "Satyaprakasha. effectiveness of multi media teaching on process skill in biology," International Journal Of Informative \& Futuristic Research, vol. 1(8), 2014.

[27] Sagala, N. L., Rahmatsyah, Mariati, P. S. "The influence of problem based learning model on scientific process skill and problem solving ability of student," IOSR-J RME, vol. 7(4), 2017. https://doi.org/10.9790/73880704040109

[28] Mutisya, S. M., Rotich, S., \& Rotich, P. K. "Conceptual understanding of science process skills and gender stereotyping: A critical component for inquiry teaching of science in Kenya S Primary f Schools," Asian Journal of Social Sciences and Humanities, vol. 2(3), pp. 359-369, 2013. Http://Hdl.Handle.Net/123456789/6791

[29] Darmaji., Kurniawan, D. A., Parasdila, H., \& Irdianti. "Description of science process skills' physics education students at Jambi University in temperature and heat materials," The Educational Review, USA, vol. 2(9), vol. 485498, 2018. http://dx.doi.org/10.26855/er.2018.09.004

[30] Darmaji., Kurniawan, D. A., Irdianti, "Physics education students' science process skills," International Journal of Evaluation and Research in Education, vol. 8(2), pp. 293-298, 2019. 